Atmosferik soğuk plazma uygulamasının titanyum meş üzerindeki etkilerinin in vitro olarak değerlendirilmesi

\section{Evaluation of the effect of atmospheric cold plasma application on titanium mesh as In vitro}

Yrd. Doç. Dr. Hüseyin Akçay

İzmir Katip Çelebi Üniversitesi, Diş Hekimliği Fakültesi, Ağız Diş ve Çene Cerrahisi A.D., Izmir

Arş. Gör. Harun Görgülü

İzmir Katip Çelebi Üniversitesi, Diş Hekimliği Fakültesi, Ağız Diş ve Çene Cerrahisi A.D., Izmir

Yrd. Doc. Dr. Utku Kürşat Ercan

İzmir Kațip Çelebi Üniversitesi, Mühendislik ve Mimarlık Fakültesi, Biyomedikal Mühendisliği Bölümü, İzmir

Yrd. Doç. Dr. Murat Ulu

İzmir Katip Celebi Üniversitesi, Dis Hekimliği

Fakültesi, Ağız Diş ve Çene Cerrahisi A.D., Izmir

Arș. Gör. Fatma İbiş

İzmir Katip Celebi Üniversitesi, Mühendislik ve Mimarlık Fakültesi, Biyomedikal Mühendisliği Bölümü, İzmir

\section{Arş. Gör. Emina Afra Demirci}

İzmir Katip Celebi Üniversitesi, Mühendislik ve Mimarlık Fakültesi, Biyomedikal Mühendisliği Bölümü, İzmir

\section{Yrd. Doç. Dr. Ozan Karaman}

İzmir Katip Çelebi Üniversitesi, Mühendislik ve Mimarlık Fakültesi, Biyomedikal Mühendisliği Bölümü, İzmir

Geliş tarihi: 5 Mayıs 2017

Kabul tarihi: 15 Ağustos 2017

doi: 10.5505/yeditepe.2018.06078

\section{Yazışma adresi:}

Arş. Gör. Harun Görgülü

İzmir Katip Çelebi Üniversitesi, Diş Hekimliği Fakültesi Ağız Diş ve Çene Cerrahisi A. D.

Aydınlıkevler Mahallesi, 6782. Sk. No:48, 35640

Çiğli/İzmir

Tel: 00905554289863

E-posta: harungorgulu89@hotmail.com
ÖZET

Amaç: Bariyer membranlar kemik defektlerinde boş bir alan oluşturması ve kan pıhtısını stabilize ederek yumuşak doku göçünün engellenmesi amacıyla kullanılmaktadır. Bariyer olarak kullanılan materyaller biyouyumluluk, doku integrasyonu, boşluk oluşturma yeteneği ve klinik kullanımını geliştirmek için bazı fiziko-kimyasal özellikler ile karakterize edilmelidir. Çalışmanın amacı çeşitli malzemelerde yüzey enerjisini ve ıslanabilirliğini artırdığı gösterilmiş olan atmosferik soğuk plazmanın(ASP), titanyum meş yüzeyine uygulanmasıyla yüzeyde meydana gelen hücre tutulumunun, protein adsorbsiyonunun ve ıslanabilirliğin açısal olarak incelenmesi ve karşılaştırılmasıdır.

Gereç ve Yöntem: 1x1 cm boyutlarında, 0,3 mm kalınlığında 1,6 mm delik çapı içeren meşler, özel üretim mikrosaniye darbeli plazma güç kaynağı kullanılarak elde edilen dielektrik bariyer deșarj (DBD) hava plazma ile muamele edilmiştir. Meşlerde kontrol grubunda herhangi bir uygulama yapılmazken, çalışma grubundaki meşlere 90 saniye boyunca mikrosaniye plazma jeneratörü ile ASP uygulaması yapılmıştır. Temas açısı ölçümleri gonyometre kullanılarak yapılmıştır.

Bulgular: Islanabilirlik değerlendirmesinde en iyi sonucun 90 saniyelik zaman diliminde ölçüldüğü görülmüştür. 6 saatlik inkübasyon periyodu sonrasında inkübatörden çıkarılan örneklerde protein miktarı arasında istatistiksel olarak anlamlı bir fark bulunmamıştır ( $p>0,05)$. 24 saatlik zaman diliminde gruplar arasında istatistiksel olarak anlamlı fark bulunmaktadır $(p<0.05)$. Hücre canlıı̆̆ı ve üremesinde 1. günde anlamlı bir fark bulunmamıştır $(p>0,05)$ ancak 3 . ve 5 . günlerde anlamlı fark bulunmuştur $(p<0,05)$.

Sonuçlar: Son zamanlarda argon atmosferik basınç plazmasının titanyum disklerde hücre yayılmasını ve ıslanabilirliği artırdığı rapor edilmiştir. Islanabilirlik açısından bakıldığında diğer çalışmalarla uyumlu olarak bizim çalışmamızda da ASP uygulamasının ıslanabilirliği artırdığı ve kontak açısını düşürdüğü sonucuna varılmıştır. Uzun dönemde hücre tutunması ve çoğalması üzerinde etkileri görülmektedir. Sonuç olarak konuyla ilgili daha ileri deneysel ve klinik çalışmalara intiyaç vardır.

Anahtar kelimeler: Meş, atmosferik soğuk plazma, protein adsorbsiyonu, hücre kültürü

\section{SUMMARY}

Aim: Barrier membranes are used to create an empty space in the bone defects and to stabilize the blood clot to prevent soft tissue migration. Materials used as barriers should be characterized by some physico-chemical properties to improve biocompatibility, tissue integration, void formation ability and clinical use. The application of atmospheric cold plasma(ACP), which has been shown to increase surface energy and wettability in various materials intended to work, angularly examines and correlates the cellular uptake, protein adsorption and wettability on the surface of the titanium mesh. 
Materials and Method: Mesh with dimensions of 1x1 cm and a diameter of $1.6 \mathrm{~mm}$ with a thickness of $0.3 \mathrm{~mm}$ was treated with air barrier plasma obtained by using a specially produced microsensor pulsed plasma power source. While there is no application in the control group, the milIs in the study group were subjected to ACP application with microgeneration plasma generator for 90 seconds. The contact angle measurements were made using a goniometer.

Results: The best result in the wettability evaluation was found to be measured in 90 seconds time. There was no statistically significant difference between the amount of protein in samples removed from the incubator after 6 hours of incubation period ( $p>0.05)$. There is a statistically significant difference between the groups in the 24-hour time frame $(p<0.05)$. No significant difference was found on day 1 in cell viability ( $p>0.05)$ and expression, but a significant difference was found on days 3 and $5(p<0.05)$. Conclusions: Recently, argon atmospheric pressure plasma has been reported to increase cell diffusion and wettability in titanium discs. In terms of wettability, in accordance with other studies, our work also resulted in the ACP application increasing the wettability and decreasing the contact angle. Long-term effects on cell adhesion and proliferation are seen. Consequently, there is a need for further experimental and clinical studies of the subject.

Keywords: Mesh, atmospheric cold plasma, protein adsorption, cell culture

\section{GíRiş}

Travma, kanser, konjenital anomaliler veya enfeksiyon geniş doku defektlerine neden olabilir. Dokuların rejenerasyonunda problem genellikle sert dokular ile ilişkilidir. Çünkü hızlı rejenere olan yumuşak dokular, başlangıçta sert doku ile kaplı olan bölgeye göç ederek yavaş rejenere olan kemik dokunun rejenerasyonunu engellemektedir. ${ }^{1-3}$ Kemik defekti sahalarında yumuşak doku göçünü engellemek ve kemik hacmini artırmak amacıyla rezorbe olan ya da rezorbe olmayan membranlar ile yapılan Yönlendirilmiş Kemik Rejenerasyonunu (YKR) da içeren çeşitli teknikler geliştirilmiştir. YKR ile kemik oluşumu beklenen sahada, bir bariyer yardımıyla sadece kemik yapımında görev alan hücrelerin ulaşması sağlanırken, hızlı çoğalma kabiliyetine sahip yumuşak dokuların ise bölgeye göçünün engellenmesi hedeflenir. ${ }^{4}$ Kemik ogmentasyonu yapılacak olan alanda boşluk oluşturmak ve böylece kan pıhtısını stabilize etmek ve yumuşak doku penetrasyonunu engellemek amacıyla bariyer membranlar kullanılabilir. ${ }^{5,6}$

Bariyer olarak kullanılan malzemeler biyouyumluluk, doku uyumu, hücre oklüzyonu, boşluk oluşturma yeteneği ve klinik kullanım kolaylığı temin etmek üzere bazı fiziko-kimyasal özellikler ile karakterize edilmelidir. ${ }^{6}$
Titanyum materyallerde kesim, asitleme gibi yüzey işlenmesi için yapılan işlemler sonrasında yüzeyde hidrokarbon tabakası oluşmaktadır. ${ }^{7-9}$ Titanyum yüzeylerin hidrokarbon ile kontaminasyonu yüzeyin biyolojik olarak yaşlanmasına ve yüzeyde osteoblast aktivitesinde azalmaya neden olmaktadır.7-9 Işlenmiş bir titanyum yüzeyin olgunlaşması 4 haftalık bir süre almaktadır. Olgunlaşan titanyum yüzeyinde oluşan karbon tabakası titanyumun hidrofobik özellik kazanmasına neden olmaktadır. Hidrofobik olan yüzeye osteoblastlar ve proteinler daha az ataşman göstermektedir. Bu durum da kemik iyileşmesini olumsuz yönde etkilemektedir. ${ }^{10}$

Plazma maddenin dördüncü hali olarak bilinmekte ve iyonize gaz, serbest elektronlar, yüklü parçacıklar ve elektriksel olarak uyarılmış moleküller ve atomlardan oluşmaktadır. ${ }^{11,12}$ Biyomedikal uygulamalarda kullanılan atmosferik basınç plazması işleminin, reaktif ürünlerin yüksek konsantrasyonları nedeniyle yüzeyin kimyasını ve enerjisini etkili bir şekilde değiştirdiği gösterilmiştir. ${ }^{13}$ Plazma uygulamasının, CaP kaplı titanyum yüzeylerde, yüzey etrafındaki kemik gelişimini artırdığı rapor edilmiştir. ${ }^{14}$

Titanyum yüzeylerin özellikleri; protein adsorbsiyonu, hücre-yüzey ilişkileri, yüzeyde hücre tutunması ve gelişmesi gibi süreçleri yakından etkilemektedir. ${ }^{15}$ Titanyum yüzey özelliklerinden olan ıslanabilirlik, yara iyileşmesinin erken fazlarında sağladığı avantajlar ve osteointegrasyonu artırması açısından önemlidir. ${ }^{16,17}$

Çalışmanın amacı çeşitli malzemelerde yüzey enerjisini ve ıslanabilirliğini artırdığı gösterilmiş olan atmosferik soğuk plazmanın (ASP), titanyum meş yüzeyine uygulanmasıyla yüzeyde meydana gelen protein adsorbsiyonunun ve Islanabilirliğin açısal olarak incelenmesi ve karşılaştırılmasıdir.

\section{GEREÇ VE YÖNTEM}

\section{Atmosferik Soğuk Plazma Muamelesi}

1x1 cm boyutlarında, 0,3 mm kalınlığında 1,6 mm delik çapı içeren meşler, özel üretim mikrosaniye darbeli plazma güç kaynağı (Advanced Plasma Solutions, Malvern, $\mathrm{PA}, \mathrm{ABD}$ ) kullanılarak elde edilen dielektrik bariyer deşarj (DBD) hava plazma ile muamele edilmiștir. Meşlerin ASP ile yapılan muamelesi, $31,4 \mathrm{kV}$ voltaj, $1,5 \mathrm{kHz}$ frekans, $6 \mathrm{~W}$ güç ve $10 \mu$ s darbe genliği parametreleri ve $2 \mathrm{~mm}$ deşarj mesafesinde 90sn boyunca yapılmıştır.

\section{Islanabilirliğin Değerlendirilmesi}

Projede kullanılacak olan tüm meşler uygun koşulların sağlanması ve olgunlaşması amacıyla $134^{\circ} \mathrm{C}$ 'de 15 dakika otoklavda (Nüve, Ankara, Türkiye) steril edilip daha sonra karanlık bir ortamda 4 hafta boyunca bekletilmiştir. Böylece yüzeyde gerekli düzeyde karbonizasyon oluşarak uygun koşullar sağlanmıştır. Çalışma öncesi her gruptan 3 adet olmak üzere toplam 6 titanyum meş üzerinde Islanabilirlik değerlendirilmiştir. 
Meşlerde kontrol gurubunda herhangi bir uygulama yapılmazken, çalışma gurubundaki meşlere 90 saniye boyunca mikrosaniye plazma jeneratörü ile ASP uygulaması yapılmıştır. Temas açısı ölçümleri gonyometre (KSV Attension Theta) kullanılarak yapılmıştır. Bu amaç için $4 \mu$ l distile su plazma ile muamele edilen plak yüzeylerine damlatılmıştır. Gonyometre cihazının kendi yazılımı kullanılarak, su damlasının sol ve sağ taraflarında açı ölçümleri alınmıştır. Herhangi bir hatalı ölçüme karşı tüm ölçümler en az iki defa tekrar edilmiştir. Alınan sonuçların Student $t$ testi ile istatiksel analizi yapılmıştır.

\section{Protein Adsorbsiyonunun Değerlendirilmesi}

Protein adsorbsiyonu için $0,3 \mathrm{~mm}$ kalınlığında toplam 2 adet titanyum meş (Ramed, İzmir, Türkiye) kullanılmıştır. Meşlerin her biri kültür kaplarına koyulmak üzere 1x1 cm boyutlarında 6 parçaya, toplamda 12 parçaya bölünüp kültür kaplarına yerleştirilmiştir. Kültür kaplarına yerleştirmeden önce daha önce tarif edildiği şekilde plazma muamelesi yapılmıştır.

Protein adsorbsiyonunu değerlendirmek için model protein olarak sığır serum albümini (Pierce Biotechnology, Rockford, IL) ve sığır plazma fibronektini (Sigma-Aldrich, St Louis, MO) kullanılmıştır. 1:1 protein-salin oranında ka-

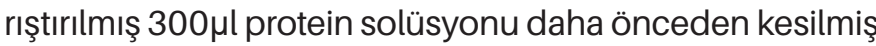
olan titanyum meşleri barındıran 12 delikli kültür kaplarına eklenmiştir. Kesilen meşler kültür kabında fikse edilmeden stabil bir şekilde bulundurulmuştur. Daha sonra $37^{\circ} \mathrm{C}^{\prime} \mathrm{de}$ steril nemli koşullar altında 6 ila 24 saat inkübasyon süresi boyunca kültür kaplarında bekletilmiştir. Adezyon göstermeyen proteinleri içeren çözelti uzaklaştırılmış ve $37^{\circ} \mathrm{C}$ 'de 60 dakika boyunca mikro-bisinkoninik asit (Pierce Biotechnology, Rockford, IL) ile karıştırılmıştır. Protein miktarı 562nm'de bir mikroplak okuyucusu (Synergy HTX Multi-Mode Reader, ABD) kullanılarak ölçülmüştür. Protein adsorbsiyon testi için test kiti içerisinde bulunan sığır albümin çözeltisi kullanılarak, deney gruplarındaki protein adsorbsiyonu ölçümünde kullanılmak üzere standart eğrisi çizilmiştir. Deney gruplarındaki protein adsorbsiyonu bu standart eğri kullanılarak belirlenmiş̦tir.

Protein adsorbsiyon seviyeleri, kontrol grupları \%100 adsorbsiyon kabul edilerek normalize edilmiş ve yüzdesel adsorbsiyon olarak ifade edilmiştir.

\section{Hücre kültürü ve Canlııı Analizi Testi}

Çalışmada kullanılan sıçan kemik iliği kaynaklı mezenkimal kök hücre (MKH) hattı Ege Üniversitesi Hayvan Hücre Kültürü ve Doku Mühendisliği Araştırma Grubundan temin edilmiştir. Rutin hücre kültürü sırasında alfa modfikasyonlu minimum essential besi ortamı ( $\alpha$-MEM) (Sigma-Aldrich, Steinheim) besi ortamı \%10 fetal sığır serumu (fetal bovine serum-FBS) (Sigma-Aldrich, Steinheim), \%1 L-glutamin (Gibco, Grand Island, US), ve \% 0,1 penisilin/streptomisin ile zenginleştirilerek kullanılmıştır. Hücreler $37^{\circ} \mathrm{C}$ ve $\% 5 \mathrm{CO}_{2}$ hava içeren inkübatörde kültüre edilmiştir.
MKH 25,000 hücre/örnek yoğunluğu kullanılarak direkt olarak titanyum meş üzerine ekilmiştir. Titanyum meşler üzerinde belli aralıklarla açılmış dairesel delikler bulunmasından dolayı, hücrelerin delikler arasındaki titanyum yüzeyde kalmasına özen göstererek ekilmiştir. Hücre canlıık analizi 3-(4,5-dimethylthiazol-2-yl)-2,5-diphenyltetrazolium bromide (MTT) (Cell Proliferation Kit (I), Roche $\mathrm{GmbH}$, Mannheim, Almanya) testi üretici talimatları izlenerek 1, 3 ve 5. günlerde yapılmışıı. \%10 MTT solüsyonu içeren serumsuz besi ortamı hücreler üzerine eklenerek 2 saat inkübasyona bırakılmış ve daha sonra dimetil sülfoksit (DMSO) (Sigma Aldrich, St. Louis, Missouri, ABD) eklenerek optik yoğunluk Mikro plaka okuyucu (Synergy ${ }^{\text {tm }}$ HTX- BioTek, Winooski, VT, ABD) ile 570 nm'de (BioTek, Winooski, VT, $A B D)$ ölçülmüştür.

\section{BULGULAR}

Çalışmada protein adsorbsiyonu ölçümü için toplamda 12 adet $1 \times 1 \mathrm{~cm}$ ebatlarında titanyum meş kullanılmıştır. Titanyum meşler 2 gruba ayrilıp 6 ve 24 saat olmak üzere 2 zaman diliminde protein adsorbsiyonu değerlendirmesi yapılmıştır. 6 saatlik zaman dilimi için toplamda 6 adet titanyum meş 2 alt gruba ayrımıştır. Alt gruptaki 3 titanyum meşe 90 saniye süreyle ASP uygulaması yapılmış ve diğer 3 titanyum meşe ise herhangi bir uygulama yapılmadan kültür kaplarına konmuştur. 24 saatlik zaman diliminde ise toplamda 6 titanyum meş bulunup bunların yarısına 90 saniye plazma uygulanırken yarısına ise uygulama yapılmamıştır.

6 saatlik inkübasyon periyodu sonrasında inkübatörden çıkarılan örneklerde protein miktarı değerlendirilmiş olup, plazma grubundaki protein miktarı kontrol grubundaki başlangıçtaki protein miktarına göre yüzdesel olarak normalize dilmiştir. Bu işlem için kontrol grubunda yapılan spektrofotometrik ölçüm sonucu \%100 protein adsorbsiyonu olarak değerlendirilirken bu ölçüme bağlı olarak plazma grubundaki protein adsorbsiyonu \%103 olarak hesaplanmıştır. Bu sonuçlara göre gruplar arasında istatiksel olarak anlamlı bir fark bulunmamıştır (Grafik 1).

24 saatlik inkübasyon periyodunda kontrol grubundaki 100 birim olan protein miktarı plazma grubunda 147 birim olarak ölçülmüştür. Uzun dönem sonuçlarına göre gruplar arasında istatistiksel olarak anlamlı fark bulunmaktadır (Grafik 1).



Grafik 1. Gruplar arasındaki protein miktarındaki artış $(*: p<0,05)$ 
Islanabilirlik ölçümü için uygun zaman dilimi pilot bir çalışma ile belirlenmiş olup bu amaca yönelik çeşitli zaman dilimlerinde plazma uygulaması yapılmıştır. Pilot çalışma sonucunda ASP uygulama süresinin artışı ile temas açısının düştüğü fazda bu ilişkinin 90 saniye ASP uygulama süresine kadar devam ettiği ve 90 saniyeden fazla ASP uygulaması ile temas açısının daha fazla düşmeyip bir platoya ulaşıı̆ı görülmüştür. Bu nedenle çalışmanın tüm aşamalarında plazma uygulaması periyodu 90 saniye olarak seçilmiştir (Grafik 2).

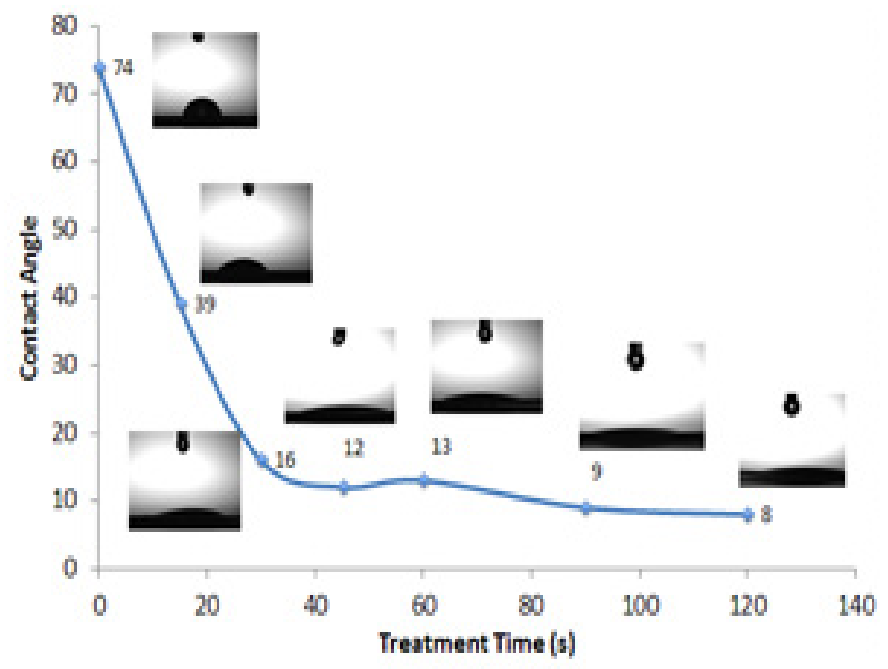

Grafik 2. Çeşitli zaman dilimlerinde kontak açısının değerlendirilmesi

Toplam 6 adet 0,3 $\mathrm{mm}$ kalınlığında 1x1 $\mathrm{cm}$ boyutlarındaki düz plaklar 2 gruba ayrılmıştır. Gruplardan birine plazma uygulanırken kontrol grubuna herhangi bir işlem uygulanmamıştır.

Kontak açısı ölçümleri yapılan titanyum plakların, ortalama açı değerleri kontrol grubunda $73,8^{\circ}$ hesaplanırken bu değer 90 . saniyede $8,4^{\circ}$ olarak hesaplanmıştır (Resim 1).

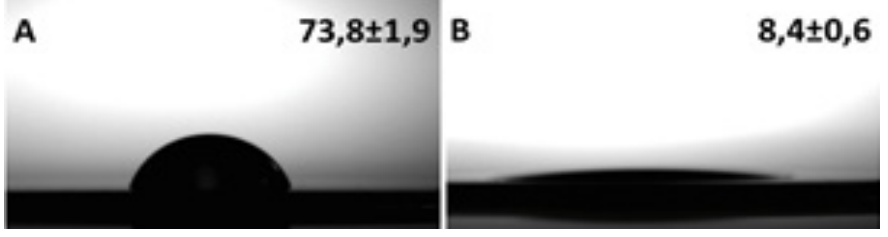

Resim 1.0 ve 90 saniyelik zaman dilimlerinde su damlalarının görüntüsü (AçıISD) Bu sonuçlara göre gruplar arasında istatiksel olarak anlamlı bir fark bulunmaktadır.

Titanyum meşler üzerine uygulanan plazma muamelesinin hücre canlılığına ve bölünmesine olan etkisi değerlendirilmiştir. Kontrol meşleri yüzeyinde 1, 3 ve 5. günlerde belirlenen hücre sayıları 1,86×104, 3,01×104 ve 8,96×104 iken plazma uygulaması yapılan meşlerin yüzeyinde aynı

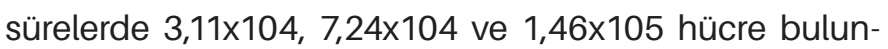
maktadır. Hücre çoğalması test sonuçlarına göre 3 ve 5 . günlerde kontrol ve plazma grubu arasında hücre çoğalması arasında anlamlı bir fark olduğu belirlenmiștir (Grafik 3).

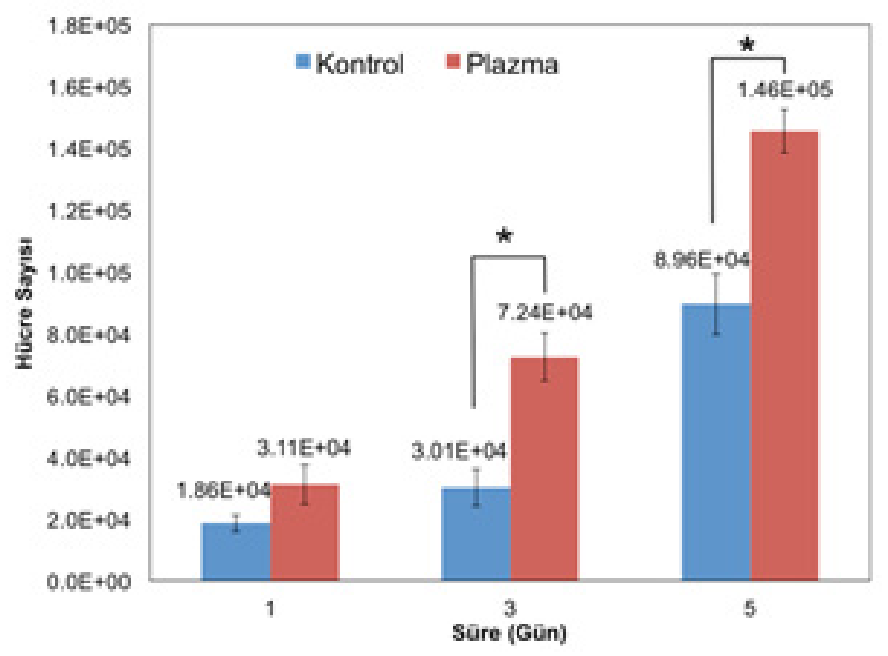

Grafik 3. Gruplar arasında hücre çoğalmasının karşılaştırılması $(*: p<0,05)$

\section{TARTIŞMA}

Plazma uygulaması yüzey işlemleri ve kaplamalar, atık imha, kimyasal sentez, işleme ve yüksek hassasiyetli plazma kaynağı gibi alanlarda kullanılmaktadır. Termal plazmaların aksine; termal olmayan plazmalar nispeten daha az tahribat gösteren karakteri ve daha yumuşak bir kimyasal reaktivite ile kombine olarak temizleme ve aşındırma, yüzey mühendisliği, adezyon geliştirme ve biyomateryal geliştirmede kullanılmaktadır. ${ }^{18,} 19$

Termal olmayan plazmalar diş hekimliği alanında kullanılmaktadır ve yüzey ıslanabilirliğini artırdığı çeşitli çalışmalarda rapor edilmektedir. ${ }^{20,}{ }^{21}$ Önceki çalışmalarda, ASP uygulamasının silikon ölçü malzemelerinin değme açısını $63^{\circ}$ den $13^{\circ}$ ye düşürdüğü rapor edilmiştir. ${ }^{20}$ Yine bir diğer çalışmada, akrilik rezin materyallerinin ASP ile muamelesi sonucu istatistiksel olarak anlamlı şekilde hidrofilisite kazandığı gösterilmiştir. ${ }^{21}$ Ayrıca, Valverde ve ark. ${ }^{22} 24$ adet zirkonyum disk üzerinde ASP'nin yüzey enerjisi üzerine etkilerini incelemişlerdir. Çalışmanın sonuçları karbon elementinde azalma ve oksijen elementinde artma olduğunu göstermektedir. Polar komponentlerde plazma uygulaması yapılan guruplarda artış görülmektedir. Sonuç olarak ise ıslanabilirliği artırdığını rapor etmişlerdir. Benzer olarak plazma uygulamasının titanyum yüzeyler üzerinde özellikle hidroksil $(\mathrm{OH})$ gruplarındaki artışa bağlı olarak yüzeyin hidrofilisitesini artırdığı bildirilmiştir. ${ }^{23}$ Bunun yanında, ibiş ve ark. farklı implant malzeme yüzeylerinin ASP ile muamelesi sonucu hidrofilik özellik kazandığını göstermiştir. ${ }^{24}$ Bu çalışmada elde edilen ASP uygulaması sonucu yüzey ıslanabilirliğinin arttığına dair sonuçlar, literatür ile uyum göstermekte olup, plazma oluşumu sırasında açığa çıkan reaktif oksijen türlerinin titanyum yüzey ile reaksiyona girerek, titanyum meş yüzeyine $\mathrm{OH}$ gibi polar grupların eklenmesi sonucu meş yüzeyinin hidrofilisitesinin arttığı düşünülmektedir.

Son zamanlarda argon atmosferik basınç plazmasının titanyum disklerde hücre yayılmasını ve ıslanabilirliği ar- 
tırdığı rapor edilmiştir. ${ }^{25}$ Materyallerin ıslanabilirliği direkt olarak yüzeyin hidrofilitesi ile ilișkilidir ve bu durumun artırılması son zamanlarda ilgi görmektedir. Çünkü son bulgular konak doku ile titanyum yüzey arsındaki etkileşimin hidrofilik yüzeylerde daha yüksek olduğunu göstermektedir. Kimyasal lüminesan algılama sonuçlarında; deneyden 24 saat önce ultraviyole-A ile birlikte plazma kaynaklı iyon implantasyonu yapılan diskler daha fazla serum fibronektin adsorbsiyonu göstermektedir. Bu durum artmış yüzey hidrofilitesinden kaynaklanmaktadır., ${ }^{78}$ Duske ve ark. ${ }^{26}$ titanyum dental implant malzemesinin ASP ile muamelesi sonucu implant yüzeyinde ASP uygulamasından 24 saat sonra anlamlı şekilde hücre tutunmasında artış gözlendiğini rapor etmişlerdir.

Bu çalışmada yüzey hidrofilitesini artırmak için titanyum meş ve plaklara ASP uygulaması yapıımıştır. Çalışmamızda protein adsorbsiyonu ve ıslanabilirliği değerlendirmek için insan biyolojisine en uyumlu olan titanyum materyalinden yapılmış plak ve meşler kullanıımıştır. Islanabilirlik açısından bakıldığında diğer çalışmalarla uyumlu olarak bizim çalışmamızda da ASP uygulamasının ıslanabilirliği artırdığı ve kontak açısını düşürdüğü sonucuna varıımıştır. Bunun bir etkisi olarak model protein olarak kullanılan serum albümin ve plazma fibronektinin titanyum yüzeye tutunması ve yüzeyde hareketinde artış beklenmektedir. Çalışmamızın kısa dönem verilerine bakııdığında 6 . saatte alınan sonuçlarda anlamlı bir artışın olmaması, proteinin tutunması için gerekli zamanın kat edilmemiş olmasından kaynaklandığı düşünülmüştür. Uzun dönem verilere bakıldığında 24. saatte protein tutunmasında \%47'lik bir artışın olduğu gözlenmiştir. Bu durum ise ıslanabilirliğin protein tutunmasında etkili olduğunu göstermektedir. Bununla birlikte, ASP uygulaması ile ıslanabilirliği artan meşlerin hücre çoğalmasını da anlamlı oranda arttırdığı görülmüştür.

\section{SONUÇLAR}

Sonuçlar YKR uygulamalarında bariyer olarak kullanılan titanyum meş yüzeylerine 90 saniyelik ASP uygulamasının kemik oluşumunu olumlu yönde etkileyeceğini işaret etmekte olup konuyla ilgili daha ileri deneysel ve klinik in vivo çalışmalara intiyaç vardır. Bu çalışmada ASP uygulaması pilot çalışmaya bağlı olarak 90 saniye olarak belirlenmiş olsa da, klinikte muhtemel pratik uygulamalar göz önüne alındığında kullanılan farklı plazma sistemleri ve titanyum meş geometrilerine bağlı olarak farklı sürelerdeki ASP uygulamalarını içeren çalışmaların gerekli olduğu önerilmektedir.

\section{Teşekkür}

Çalışmamız İzmir Kâtip Çelebi Üniversitesi Bilimsel Araştırmalar Koordinatörlüğü tarafından desteklenmektedir. Bu desteğinden dolayı IKKÇÜ BAP Koordinatörlüğü'ne teşekkürlerimizi sunarız.

\section{KAYNAKLAR}

1. Ashammakhi N, Makela A, Vihtonen K, Rokkanen P, Tormala P. Absorbable membranes for bone repair: an experimental study on rabbits. Clin Mater 1994; 17: 113-118.

2. Hurzeler MB, Quinones CR, Schupbach P. Guided bone regeneration around dental implants in the atrophic alveolar ridge using a bioresorbable barrier. An experimental study in the monkey. Clin Oral Implants Res. 1997; 8: 323 331.

3. Baumann A, Burggasser G, Gauss N, Ewers R. Orbital floor reconstruction with an alloplastic resorbable polydioxanone sheet. Int J Oral Maxillofac Surg 2002; 31: 367373.

4. Nyman S, Lindhe J, Karring T, Rylander H. New attachment following surgical treatment of human periodontal disease. J Clin Periodontol 1982; 9: 290-296.

5. Linde A, Thoren C, Dahlin C, Sandberg E. Creation of new bone by an osteopromotive membrane technique: an experimental study in rats. J Oral Maxillofac Surg 1993; 51: 892-897.

6. Karring T, Nyman S, Gottlow J, Laurell L. Development of the biological concept of guided tissue regeneration-animal and human studies, Periodontol 2000 1993; 1: 26 35.

7. Aita $\mathrm{H}$, Hori N, Takeuchi M, Suzuki T, Yamada M, et. al. The effect of ultraviolet functionalization of titanium on integration with bone. Biomaterials 2009; 30: 1015-1025.

8. Att W, Hori N, Takeuchi M, Ouyang J, Yang Y, et. al. Time-dependent degradation of titanium osteoconductivity: an implication of biological aging of implant materials. Biomaterials 2009; 30: 5352-5363.

9. Att W, Ogawa T. Biological aging of implant surfaces and their restoration with ultraviolet light treatment: a novel understanding of osseointegration. Int $\mathrm{J}$ Oral Maxillofac Implants 2012; 27: 753-761.

10. Hirota M, Ikeda T, Tabuchi M, Iwai T, Tohnai I, et. al. Effect of ultraviolet-mediated photofunctionalization for bone formation around medical titanium mesh. J Oral Maxillofac Surg 2014; 72: 1691-1702.

11. Joshi SG, Cooper M, Yost A, Paff M, Ercan UK, et. al. Nonthermal dielectric-barrier discharge plasma-induced inactivation involves oxidative DNA damage and membrane lipid peroxidation in Escherichia coli. Antimicrobial agents and chemotherapy 2011; 55: 1053-1062.

12. Ercan UK, Wang $H$, Ji H, Fridman G, Brooks AD, et. al. Nonequilibrium Plasma-Activated Antimicrobial Solutions are Broad-Spectrum and Retain their Efficacies for Extended Period of Time. Plasma Processes and Polymers 2013; 10: 544-555.

13. Sista S, Wen C, Hodgson PD, Pande G. The influence of surface energy of titanium-zirconium alloy on osteoblast cell functions in vitro. J Biomed Mater Res A 2011; 97: 27-36. 
14. Junker R, Manders PJ, Wolke J, Borisov $Y$, Jansen JA. Bone-supportive behavior of microplasma-sprayed CaP-coated implants: mechanical and histological outcome in the goat. Clin Oral Implants Res. 2010; 21: 189-200. 15. Buser D, Broggini N, Wieland M, Schenk R, Denzer A. Enhanced bone apposition to a chemically modified SLA titanium surface, J Dent Res 2004; 83: 529-533.

16. Rupp F, Scheideler L, Eichler M, Geis-Gerstorfer J. Wetting behavior of dental implants. Int $\mathrm{J}$ Oral Maxillofac Implants 2011; 26: 1256-1266.

17. Hirakawa $Y$, Jimbo R, Shibata $Y$, Watanabe I, Wennerberg A, et. al. Accelerated bone formation on photoinduced hydrophilic titanium implants: an experimental study in the dog mandible, Clin Oral Implants Res 2013; 24: 139 144.

18. Fridman G, Friedman G, Gutsol A, Shekhter AB, Vasilets VN, . Applied plasma medicine. Plasma Processes and Polymers 2008; 5: 503-533.

19. Chu PK, Chen J, Wang L, Huang N. Plasma-surface modification of biomaterials. Materials Science and Engineering: R: Reports 2002; 36: 143-206.

20. Hesby RM, Haganman CR, Stanford CM. Effects of radiofrequency glow discharge on impression material surface wettability, J Prosthet Dent 1997; 77: 414-422.

21. Ozden N, Akaltan F, Suzer S, Akovali G. Time-related wettability characteristic of acrylic resin surfaces treated by glow discharge, J Prosthet Dent 1999; 82: 680-684.

22. Valverde GB, Coelho $P G$, Janal MN, Lorenzoni FC, Carvalho RM, . Surface characterisation and bonding of Y-TZP following non-thermal plasma treatment, J Dent 2013; 41: 51-59.

23. Germanier $Y$, Tosatti S, Broggini N, Textor M, Buser D. Enhanced bone apposition around biofunctionalized sandblasted and acidetched titanium implant surfaces. Clin Oral Implants Res 2006; 17: 251-257.

24. Ibis $F$, Oflaz $H$, Ercan UK. Biofilm Inactivation and Prevention on Common Implant Material Surfaces by Nonthermal DBD Plasma Treatment. Plasma Medicine 2016; 6: 33-45.

25. Duske K, Koban I, Kindel E, Schroder K, Nebe B, et. al. Atmospheric plasma enhances wettability and cell spreading on dental implant metals. J Clin Periodontol 2012; 39: 400-407.

26. Duske K, Jablonowski L, Koban I, Matthes R, Holtfreter $B$, . Cold atmospheric plasma in combination with mechanical treatment improves osteoblast growth on biofilm covered titanium discs. Biomaterials 2015; 52: 327-334. 